\title{
POROUS PERMEABLE HIGH-ALUMINA CERAMIC MATERIALS FOR MACRO- AND MICROFILTRATION
}

\author{
Yurij G. PAULIUKEVICH ${ }^{\mathrm{a}}$, Olga KIZINIEVIČb ${ }^{\mathrm{b}}$, Yurij A. KLIMASH ${ }^{\mathrm{a}}$, \\ Mikalai M. HUNDZILOVICH ${ }^{\mathrm{a}}$, Giedrius GIRSKAS ${ }^{\mathrm{b}}$ \\ ${ }^{a}$ Department of Glass and Ceramic Technology, Belarusian State Technological University, \\ Sverdlova str. 13 a, 220006, Minsk, Belorussia \\ ${ }^{b}$ Research Institute of Building materials and Products, Vilnius Gediminas Technical University, \\ Sauletekio al. 11, LT-10223 Vilnius, Lithuania
}

Received 26 October 2015; accepted 20 November 2015

\begin{abstract}
Absctract. Designed composition of ceramic mass for high-alumina porous permeable ceramic material for disperse micro hydro systems. The filler used alumina fraction 100-250 microns, as a binder system studied refractory clay Veselovskaya-medicalglass-gibbsite. Formation of material carried by dry pressing at a pressure $60 \mathrm{MPa}$, the temperature of synthesis was $1250-1350{ }^{\circ} \mathrm{C}$, holding at the maximum temperature $-1 \mathrm{~h}$. The processes occurring in the binder during sintering was investigated. The effect of the sintering temperature of the material, the amount of binder composition on the acid resistance, mechanical strength, porosity and permeability of open high-alumina permeable porous material was investigated. The structure and phase composition of the submissions received, the average pore diameter was $10 \mathrm{~mm}$, it can be used for microfiltration of liquids and gases, the material is homogeneous at the macro level, the structure is represented by an extensive network of channels of pores. Phase composition is represented mainly corundum and mullite.

The material has the following set of physico-chemical properties: open porosity $46.41-49.74 \%$, acid resistance 99.24-99,65\%, mechanical strength in compression $6.41-12.53 \mathrm{MPa}$, permeability $5.32 \cdot 10^{-8} \mathrm{~m}^{2}$.
\end{abstract}

Keywords: ceramic membrane, filler, binder, porosity, permeability, acid resistance, microstructure.

\section{Introduction}

Currently permeable ceramic materials are widely used in many industries: food, pharmaceutical, chemical and petro-chemical industries. Permeable ceramic materials based on aluminum oxide have high performance properties. Due to high mechanical strength, chemical stability and bioinertness of high-alumina ceramic materials are used for microfiltration of milk and dairy products concentration, purification and clarification of fruit and vegetable juices, for filtering hydraulic fluids in the production of alcoholic beverages, water purification.
Creation of required microstructure of high alumina ceramic filters is possible due to controlling of the phase formation and sintering processes of ceramic mass under the action of reactive additives and binders. Composition and amount of binders in ceramic masses hold much significance of permeability, mechanical strength and chemical stability of ceramic filters (Burggraaf 1996; Emchenko 2006; Tsapatsis 1994).

The formulation containing 50\% kaolin, $20 \%$ limestone, $10 \%$ potassic feldspar, $10 \%$ albite and $10 \%$ quartz (dry basis) was considered the most suitable for separation of suspended solids from liquid suspensions (microfiltration) (Simao et al. 2015).

Corresponding author:

Y. Pauliukevich E-mail: pauliukevich@belstu.by 
Permeability of porous ceramics considering the Klinkenberg and inertial effects porous ceramics have become key materials in demanding filtration applications because their microstructure and composition can be tailored to present a very favorable combination of features, including high permeability, specific surface area, mechanical strength, thermal inertness, and chemical resistance to aggressive environments (Scheffler, Colombo 2005; Studart et al. 2006).

The aim of this paper investigation the porous permeable high alumina ceramic materials.

\section{Materials and methods}

The physicochemical properties of permeable high alumina ceramics, the effect of the binder composition and sintering temperature on structure formation and phase composition were investigated for development of microstructured high alumina ceramic filters.

In this study, the ceramic filters were prepared using technical grade GK-2 alumina (GOST 6912-87) as a filler, "Keramik-Vesko" refractory clay (GOST 916775), waste glass HT-1 (GOST 19808) and gibbsite GB-1 (TU 1711-004-00200992) as a binder.

Alumina is the main structure-forming component which imparts high chemical and thermal resistances of the ceramic materials. Due to the spherulitic porous structure of the alumina, its particles have a high surface energy and a contact area between the grains, which creates favorable conditions for sintering.

"Keramik-Vesko" refractory clay GOST 9167-75 (the Republic of Ukraine) is a kaolinite-hydromica semi-acid fine dispersed plastic clay. The content of the clay particles smaller than $0.005 \mathrm{~mm}$ is $88.0-99.8 \%$. The plasticity index of the clay is $15-25$. The average chemical composition of clay given in weight percentages (wt. \%) of oxides: $\mathrm{SiO}_{2}=53.46 ; \mathrm{Al}_{2} \mathrm{O}_{3}=32.0$; $\mathrm{Fe}_{2} \mathrm{O}_{3}=0.75 ; \mathrm{TiO}_{2}=1.10 ; \mathrm{CaO}=1.10 ; \mathrm{MgO}=0.40 ;$ $\mathrm{Na}_{2} \mathrm{O}=0.49 ; \mathrm{K}_{2} \mathrm{O}=2.10$; loss on ignition $(\mathrm{LOI})=8.60$.

Glass HT-1 GOST 19808 (the Republic of Belarus) is a chemical- and thermal-resistant. Glass HT-1 has alumina-borosilicate composition and is used for the manufacture of medical devices. The density of the glass is $2370-2400 \mathrm{~kg} / \mathrm{m}^{3}$, the coefficient of linear expansion (5.4-5.7) $\times 10^{-6} \mathrm{~K}^{-1}$. Currently "Borisov Crystal Factory" has accumulated significant reserves of glass HT-1 waste. Glass waste is produced from upper layers of the glass HT- 1 at the draining stage. The average chemical composition of waste glass HT-1 in wt. \% of oxides: $\mathrm{SiO}_{2}=72.00 ; \mathrm{Al}_{2} \mathrm{O}_{3}=6.00 ; \mathrm{B}_{2} \mathrm{O}_{3}=10.50$; $\mathrm{CaO}=0.80 ; \mathrm{Na}_{2} \mathrm{O}=6.70 ; \mathrm{K}_{2} \mathrm{O}=1.80 ; \mathrm{BaO}=2.00$.
Gibbsite (hydrargillite) GB-1 TU 1711-00400200992 is a mineral consisting of $\gamma-\mathrm{Al}(\mathrm{OH})_{3}$. The heating of gibbsite leads to decomposition of $\gamma-\mathrm{Al}(\mathrm{OH})_{3}$ with formation of aluminum oxide $\gamma-\mathrm{Al}_{2} \mathrm{O}_{3}$, which has a high chemical activity to the components of binder, affects the sintering processes, phase and properties of the permeable ceramic material. The average chemical composition of gibbsite GB-1 in wt. \% of oxides: $\mathrm{SiO}_{2}=0.05 ; \mathrm{Al}_{2} \mathrm{O}_{3}=65.00 ; \mathrm{CaO}=0.10 ; \mathrm{MgO}=0.10$; $\mathrm{Na}_{2} \mathrm{O}=0.10 ; \mathrm{K}_{2} \mathrm{O}=0.10 ; \mathrm{LOI}=34.55$.

The content of technical grade GK-2 alumina in ceramic masses in wt. \% is 75.0-85.0; waste glass HT-1 - 3.75-12.50; "Keramik-Vesko" refractory clay 7.5-20.0; gibbsite GB-1 - 2.5-5.0. Chalk Volkovysskii GOST 17498 (the Republic of Belarus) and coke KL-1 GOST 3340 (the Republic of Belarus) were injected in ceramic mass over $100 \%$. The choice of the composition of ceramic masses is based on scientific literature analysis and the results of preliminary investigations.

Alumina was separated on the sieves, selected fractions are 100-250 $\mu \mathrm{m}$. "Keramik-Vesko" refractory clay, waste glass HT-1, gibbsite GB-1, chalk Volkovysskii and coke KL-1 were exposed to magnetic purification and grinding in a ball mill SPEEDY (Italy) by combined wet milling with humidity $40-45 \%$, residual on sieve 0.063 was $1.0-2.0 \mathrm{wt}$. \%. The ratio of grinding media to the dry weight of milled material was $1,5: 1$. Obtained slurry was mixed with alumina and dried. From the dried mixture press-powder was produced with 6-8 wt. \% humidity. Pressing was carried out on a hydraulic press at the pressure of $60 \mathrm{MPa}$. The formed samples were sintered in an electric laboratory furnace "Nabertherm" at $1250-1350^{\circ} \mathrm{C}$ with holding at the maximum temperature for $1 \mathrm{~h}$.

Thermal analysis of the ceramic materials was carried out by the DSC 404 F3 Pegasus (NETZSCH, Germany). The phase composition of the synthesized materials was studied on a DRON-7 with ionization registration of X-ray. Microstructural analysis was done by a scanning electron microscope 7600F (JEOL, Japan) with chemical analysis system EDXJED-2201 (JEOL, Japan). The degree of homogeneity of the macro structure was determined by the analysis of the results of water adsorption and drying kinetics researches of the materials. The open porosity of the material was measured by the GOST 2409 method. The mechanical strange was determined using GOST 8462 method on hydraulic press series LFM 100 (Walter + bai ag, Switzerland). 


\section{Results}

Investigation of the mechanical strength showed the values of the compressive strength of the samples obtained at a sintering temperature $1250{ }^{\circ} \mathrm{C}$ are $0.167-$ $2.083 \mathrm{MPa}, 1300{ }^{\circ} \mathrm{C}-0.291-3.125 \mathrm{MPa}, 1350{ }^{\circ} \mathrm{C}-$ $0.860-12.526 \mathrm{MPa}$. Mechanical strength is determined by nature of the porosity, caking degree and phase composition of the materials.

Moreover it was found out that the values of the mechanical strength of the permeable ceramics depend on the contact area between the structure-forming particles. The higher it is, the greater the area of mechanical load distribution is and, consequently, the higher mechanical properties are. The contact area of the particles in the material depends on the amount of binder and dispersity of filler grains. The greatest mechanical strength is achieved for samples with $25 \%$ of the binder.

The main characteristics of the permeable ceramic materials are porosity, pore size, the degree of the structure homogeneity and permeability. They determine the filtering capacity of the material and its operational properties.

Figure 1 shows scanning electron microscopy (SEM) photos of the permeable material sintered at $1350{ }^{\circ} \mathrm{C}$. For $100-250 \mu \mathrm{m}$ fraction of structure-forming particles average porous size is between $10-40 \mu \mathrm{m}$, which allows to use the material for macro- and microfiltration.

Network of opened interconnected pores preserved up to $20 \mathrm{wt}$. \%. of binder in ceramic masses. A further increase of the binder amount in the ceramic masses leads to decrease of total porosity and increase the content of closed pores which are not involved in filtration processes.

The analysis of the results of water adsorption and drying kinetics researches of the samples revealed the materials have a high degree of homogeneity of the macrostructure. The average values of open porosity of the samples obtained at a sintering temperature $1250{ }^{\circ} \mathrm{C}$ are $55.66 \% ; 1300{ }^{\circ} \mathrm{C}-49.30-54.91 \%$; $1350{ }^{\circ} \mathrm{C}-41.43-49.74 \%$.

The XRD patterns of the materials indicated that the main crystal phases are corundum and mullite. The addition of gibbsite to the ceramic masses leads to an increase of the mechanical strength due to the activation of mullite forming processes (Grigorev 2011).

Process of mullite formation in the structure of the binder can be seen in the SEM photos (Fig. 2) of
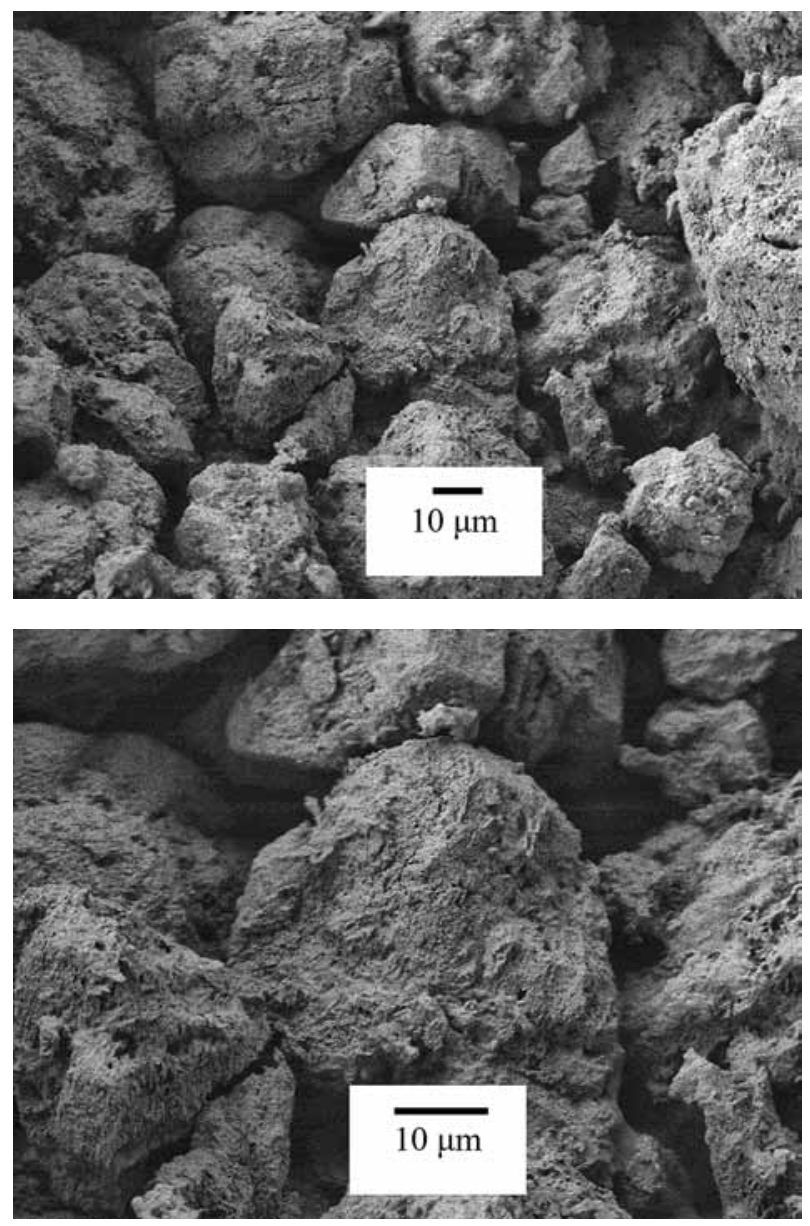

Fig. 1. SEM micrograph of the material sintered at $1350{ }^{\circ} \mathrm{C}$

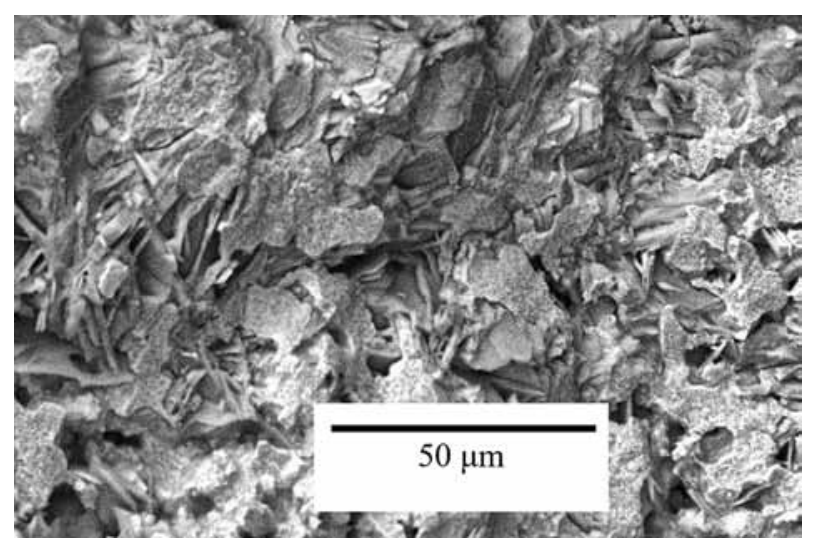

Fig. 2. The microstructure of the binder containing gibbsite

binder containing "Keramik-Vesko" refractory clay, waste glass HT-1 and 1-GB gibbsite and calcined at $1350^{\circ} \mathrm{C}$. The addition of gibbsite to the ceramic masses lead to the growth of needle crystals of mullite and the degree of crystallinity of the binding.

According to the results of differential scanning calorimetry (DSC), the ceramic masses have exothermic effect in the temperature interval $920-990^{\circ} \mathrm{C}$. This 


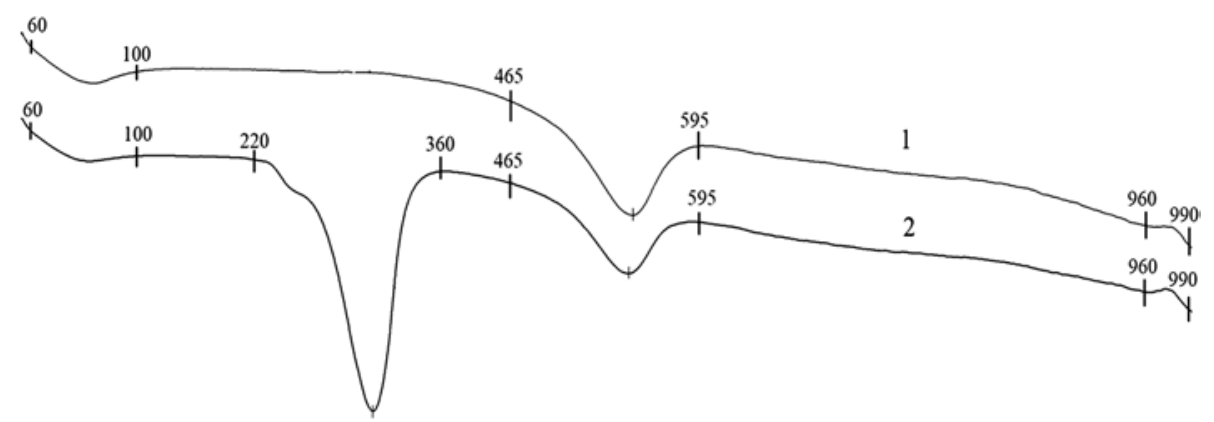

Fig. 3. DSC analysis of the binder ceramic masses without (1) and with gibbsite (2)

is caused by formation of cryptocrystalline mullite, and the value of effect depends on the content clay and gibbsite in the ceramic masses. For an equal value of clay content in the ceramic masses the high exothermic effect is higher for the masses containing gibbsite. It indicates the active chemical interactions between $\gamma-\mathrm{Al}_{2} \mathrm{O}_{3}$ and $\mathrm{SiO}_{2}$ (Fig. 3). The endothermic effect in the temperature interval $220-360{ }^{\circ} \mathrm{C}$ is due to decomposition of $\mathrm{Al}(\mathrm{OH})_{3}$.

One of the most important properties of permeable ceramic materials is permeability. It characterizes the ability of the material to infiltrate the dispersion medium and determines the performance of the filtration system. It is known that the permeability of the material depends on the porosity, pore size and shape, the structure of the pore space. The values of the permeability coefficient of the ceramic materials sintered at $1350{ }^{\circ} \mathrm{C}$ is $(4.213-5.867) 10^{-8} \mathrm{~m}^{2}$. The values of the permeability coefficient correlate with values of the opened porosity.

\section{Conclusions}

The addition of gibbsite to the ceramic masses intensifies mullite forming processes in the binder and on the surface of the filler grains. The formed mullite crystals increase mechanical strength of the permeable material.

The composition of the ceramic mass for production of the ceramic porous permeable filters was developed. The composition of the ceramic mass: 80 wt. $\%$ of technical grade GK-2 alumina, 12.5 wt. \% of "Keramik-Vesko" refractory clay, 5 wt. \% of waste glass HT-1, 2.5 wt. \% of gibbsite GB-1, chalk Volkovysskij 5 wt. $\%$ over $100 \%$.

The structure research revealed that the pore structure of the material is represented by interconnected pores with the average pore size between
$10-40 \mu \mathrm{m}$ which allows to use the material for macroand microfiltration. The increase of the binder amount in the ceramic masses leads to the increase of the amount of melt which fills the porous and decrease of the total porosity. The content of binder in the ceramic masses more than $20 \mathrm{wt}$. \% leads to sharp reduction of the performance properties.

The analysis of the results of water adsorption and drying kinetics revealed the materials have a high degree of homogeneity of the macrostructure and efficiency of filtration process.

The composition of the ceramic mass for production of the ceramic porous permeable filters was developed. The composition of the ceramic mass: 10 wt. \% of technical grade GK-2 alumina, 12.5 wt. \% of "Keramik-Vesko" refractory clay, 5 wt. \% of waste glass HT-1, 2.5 wt. \% of gibbsite GB-1.5 wt. \% of chalk Volkovysskii. The developed materials have high performance properties: acid resistance is $99.65 \%$, the mechanical compressive strength is $8.49 \mathrm{MPa}$, the permeability coefficient is $5.3210^{-8} \mathrm{~m}^{2}$, the sintering temperature is $1350^{\circ} \mathrm{C}$.

\section{Acknowledgements}

The authors would like to thank the financial support of the Belarusian Republican Foundation for Fundamental Research (project No. T15LIT-011). This work has been supported by the Research Council of Lithuania (project No. TAP-LB-15/2015).

\section{References}

Burggraaf, A. J. 1996. Fundamentals of inorganic membrane science and technology. Amsterdam: Elsevier science. 709 p. http://dx.doi.org/10.1016/s0927-5193(96)80001-5

Emchenko, I. V. 2006. Osobennosti uluchsheniya svoystv keramicheskih izdeliy putem intensifikatsii protsessov ih spekaniya. Lvov: Lvovskaya kommercheskaya akademiya. 244 p. 
Grigorev, M. V. 2011. Issledovanie mehanicheskih svoystv korundovoy keramiki pri izmenenii poristosti i razmerov kristallitov, Zhurnal Sibirskogo federalnogo universiteta 4: 113-120.

Simao, L.; Caldato, R. F.; Innocentini, M. D. M.; Montedo, O. R. K. 2015. Permeability of porous ceramic based on calcium carbonate as pore generating agent, Ceramic International 41(3): 4782-4788. http://dx.doi.org/10.1016/j.ceramint.2014.12.031

Scheffler, M. P.; Colombo, P. 2005. Cellular ceramics: structure, manufacturing, properties and applications. Weinheim: Wiley-VCH. 800 p.
Studart, A. R.; Gonzenbach, U. T.; E. Tervoort, E.; Gauckler L. J. 2006. Processing routes to macroporous ceramics: a review, Journal of the American Ceramic Society 89(6): 1771-1789. http://dx.doi.org/10.1111/j.1551-2916.2006.01044.x

Tsapatsis, M. 1994. Structure and aging characteristics of the permselective $\mathrm{SiO}_{2}$-Vycor membranes, Journal of Membrane Science 87(3): 281-296. http://dx.doi.org/10.1016/0376-7388(94)87034-9

Yurij G. PAULIUKEVICH. Assoc. Prof. at the Department of Glass and Ceramic Technology, Belarusian State Technological University. Research interests: ceramic, ceramics technology, glass technology, ceramic durability, frost resistance of ceramic.

Olga KIZINIEVIČ. PhD at the Research Institute of Building materials and products, Vilnius Gediminas Technical University. Research interests: ceramic, ceramics technology, glass technology, ceramic durability, frost resistance of ceramic.

Yurij A. KLIMASH. Assoc. Prof. at the Department of Glass and Ceramic Technology, Belarusian State Technological University. Research interests: ceramic, ceramics technology, glass technology, ceramic durability, frost resistance of ceramic.

Mikalai M. HUNDZILOVICH. PhD student at the Department of Glass and Ceramic Technology, Belarusian State Technological University. Research interests: ceramic, ceramics technology, glass technology, ceramic durability, frost resistance of ceramic.

Giedrius GIRSKAS. PhD at the Research Institute of Building Materials and Products, Vilnius Gediminas Technical University. Research interests: concrete durability, frost resistance of concrete, concrete with additives, synthetic zeolites in concrete. 